\title{
Use of Botanicals for the Management of Pulse Beetle (Callosobruchus maculatus F.) in Lentil
}

\author{
Ram B Paneru $^{1 *}$ and Gopal P Shivakoti ${ }^{1}$ \\ ${ }^{1}$ Entomology Division, Nepal Agricultural Research Council, Khumaltar, Lalitpur
}

\begin{abstract}
Some plant materials, sweet flag (Acorus calamus), goat weed (Ageratum conyzoids), lantana (Lantana camara), Indian privet (Vitex negundo), mug-wort (Artimisia vulgaris), chinaberry (Melia azederach), rice husk ash, mustard (Brassica spp.) oil and neem (Azadirechta indica) oil were evaluated for their effects against pulse beetle (Callosobruchus maculatus $\mathrm{F}$.). The powder or oil from the above plant materials were thoroughly admixed at the rate of $0.5,1$ and $2 \% \mathrm{w} / \mathrm{w}$ or v/w with lentil grains. Randomly selected 25 pulse beetle adults were exposed to the grains for each concentration of the main treatment. Rhizome powder of sweet flag, rice husk ash and mustard oil showed a significant effect in killing the pulse beetle within a week at $0.5,1$ and $2 \%$ concentrations. Neem oil was found very effective with $100 \%$ mortality of the beetle within two days. Other tested materials also showed insect killing properties but the effect was comparatively lower than that of sweet flag rhizome powder, mustard oil, neem oil and rice husk ash.
\end{abstract}

Key words: Botanicals, Callosobruchus maculates, lentil, pulse beetle

\section{Introduction}

Lentil (Lens esculenta M.) is the number one crop among pulses in terms of production and area in Nepal. It is considered as the major source of protein in the daily diet of Nepalese people, because protein from other sources has become scarce in our day to day food. The lentil has covered $50 \%$ of the total pulse area and production in Nepal (Pandey, 1994). Production potential of the crop has been increasing in Nepal because of its commercial value. It is grown both under irrigated and rainfed land and can fit under both inter and mixed cropping systems. There is a good marketing facility of the pulse and it is easy to cook. It has been observed that the pulse is highly susceptible to pulse beetles (Callosobruchus maculatus, C. chinensis) during storage. Due to invasion of the beetle, deterioration in quality and quantity of lentil grains is high in Terai and foothill region of Nepal. Room sanitation and fumigation are the commonly used and recommended control practices for management of stored grain pests. But these practices are limited to a number of farm households of Nepal, as majority of them do not have separate grain stores to ensure efficient sanitation. Many farmers have very little knowledge about the use of toxic fumigants. In the present context, use of botanicals is considered as eco-friendly and effective materials against stored grain pests.

Some indigenous plant materials have been known for their effectiveness to reduce oviposition, egg hatchability and adult emergence of pulse beetle. Chinwada and Giga (1993) reported that commercial vegetable oil and neem oil were very effective against pulse beetles till sixteen weeks to reduce oviposition, percent eggs hatching, progeny emergence and seed damage when applied at the rate of $2.5 \mathrm{ml} \mathrm{kg}^{-1}$ seeds. They also reported that mortality of these pulse beetles was more than $90 \%$. The cinnamon oil (Cinnamomum camphora N.) was toxic to the bean weevil having lethal concentration (LC) 50 $<200 \mathrm{mg}$ per ml. It has fumigant action, which caused $100 \%$ mortality with the application of 50 mg of $100 \%$ oil per 40 cubic centimeter space (Garcia, 1990). Rojesus et al. (1989) reported that the oil of goat weed (Ageratum conyzoids), Pyrethrum (Chrysenthemum indicum), Indian privet (Vitex negundo) and neem tree (Azadirachta indica) had contact toxicity, which caused mortality ranging from 43 to $90 \%$ at 100 $\mathrm{mg} \mathrm{ml} \mathrm{m}^{-1}$ for 48 hours exposure when applied by 
filter paper impregnation method. At the same concentration, the oil form of the above materials were more toxic than the powder form when mixed with the seeds. Oil treatment had $100 \%$ mortality within 24 hours. The neem oil and pyrethrum flower powder were reported the best control of pulse beetle when these products were used at the rate of $50 \mathrm{mg}$ per $\mathrm{ml}$ per $100 \mathrm{~g}$ of faba bean seeds (Bayeh and Tadese, 1996). Neem seed powder, pepper (Piper longum L.) and persian lilac (Melia azederach) seed powder were reported to protect the bean seeds from bruchid beetle's attack for up to 120 days (Negasi and Abage, 1992). The objectives of this study was to know the effectiveness of formulation, doses and methods of application of some botanicals that are found in Nepal.

\section{Materials and Methods}

The performance of eight different plant materials was evaluated against pulse beetle in the room condition at Entomology Division, Khumaltar, where the range of minimum and maximum temperatures during the experiment was $25-27^{\circ} \mathrm{C}$ and $26-27^{\circ} \mathrm{C}$, respectively for the first year $(1998 / 99)$ and $25-27^{\circ} \mathrm{C}$ and $26-29^{\circ} \mathrm{C}$, respectively in the second year (1999/00). Coarse powder of some botanicals were prepared out of shade dried rhizomes of sweet flag (Bojho) (Acorus calamus), leaves and stem of goat weeds (Ageratum conyzoids), lantana (Lantana camara), Indian privet (Vitex negundo) and Mugwort (Artemisia vulgaris) and seeds of chinaberry (Melia azederach). Rice husk ash was obtained by burning rice husk. The commercially available mustard oil was also included in the test. The MargoSom (Azadirachtin, $0.15 \%$ of Azadirachta indica) was included in the first year, while mugwort (Artemisia vulgaris) was used in the second year. Altogether there were eight main treatments. Each main treatment had three different concentrations of powder form 0.5 , 1 and $2 \% \mathrm{w} / \mathrm{w}$ and liquid form at $0.5,1,2 \% \mathrm{v} / \mathrm{w}$ ) as sub treatments. The lentil grains without any treatment served as the control treatment. Pulse beetle, which was originally collected from Mugitar, Ramechhap was multiplied and maintained in the laboratory of Entomology Division.
One hundred grams of lentil grains were thoroughly mixed with botanicals at rate of above concentrations for each sub treatment. Effects of these materials were evaluated against bruchids in lentil in a plastic container of $250 \mathrm{ml}$ capacity. Randomly selected 25 bruchid adults were exposed to each concentration of main treatments. The experiment was set up in a completely randomized factorial design in three replications. The number of dead and morbid adults was counted at an interval of 48 hours and such observations were made for up to 12 days for actual effects of each plant material. The data wherever necessary (ie mortality observed in the control treatment) were corrected (Abott, 1925). The percent data were transformed into arc sine values and analysis of variance (ANOVA) was used to analyze the data. Interaction effect was also observed so as to differentiate superior combinations for higher mortality of the pulse beetle. The mean separation was done by using Duncan's Multiple Range Test (DMRT) at 0.05 level.

\section{Results and Discussion}

Mean mortality of the pulse beetles in each treatment is presented in Table 1 for the year $1998 / 99$ and 1999/'00. The data reveal that the mortality of the adult beetles increased with the increment of exposure time to botanical extracts.

The first year experiment indicated that neem oil (@ 0.5, 1 and 2\% v/w concentrations) was very effective to cause $100 \%$ mortality of pulse beetle within 2 days. This was followed by sweet flag rhizome powder and mustard oil (@1\% and 2\% v/w) within 8 days. However, the mustard oil @ $0.5 \%$ took 12 days to kill $100 \%$ of beetles adult. Similarly, > $90 \%$ beetles were killed with rice husk ash on the $12^{\text {th }}$ day. Rest of the botanicals were comparatively less toxic to the beetles but were better than control. Similarly, the second year experiment indicated that sweet flag rhizome powder, rice husk ash and mustard oil (@ 0.5, 1 and 2\% concentrations) were effective to cause $100 \%$ mortality of the beetle within six days. The mortality in the second year experiment was comparatively faster than that of the first year. It could probably be due to 
temperature, which was slightly higher at the time of conducting the experiment during the second year. The analysis made on the data recorded in the first year was found significantly different at $\mathrm{P} \leq 0.01$ on all dates except $12^{\text {th }}$ day, while it was significantly different at $\mathrm{P} \leq 0.01$ on $2^{\text {nd }}, 4^{\text {th }}$ and $6^{\text {th }}$ day but no significant different on $8^{\text {th }}, 10^{\text {th }}$ and $12^{\text {th }}$ day in the second year.

Table 1. Mean mortality of pulse beetle (Callosobruchus maculates) on lentil grains treated with different extracts of botanicals at three concentrations (conc) up to 12 days of exposure, 1998/99 and 1999/00

\begin{tabular}{|c|c|c|c|c|c|c|c|c|c|c|c|c|c|}
\hline \multirow[t]{3}{*}{ Treatment } & \multicolumn{13}{|c|}{ Mean mortality, $\%$ and days of exposure } \\
\hline & \multirow{2}{*}{$\begin{array}{l}\text { Conc, } \\
\% \mathrm{w} / \mathrm{w}, \\
\mathrm{v} / \mathrm{w}\end{array}$} & \multicolumn{2}{|c|}{$2^{\text {nd }}$ Day } & \multicolumn{2}{|c|}{$4^{\text {th }}$ Day } & \multicolumn{2}{|c|}{$6^{\text {th }}$ Day } & \multicolumn{2}{|c|}{$8^{\text {th }}$ Day } & \multicolumn{2}{|c|}{$10^{\text {th }}$ Day } & \multicolumn{2}{|c|}{$12^{\text {th }}$ Day } \\
\hline & & $\begin{array}{l}1998 / \\
99 \\
\end{array}$ & $\begin{array}{l}1999 / \\
00\end{array}$ & $\begin{array}{l}1998 / \\
99\end{array}$ & $\begin{array}{l}1999 / \\
00\end{array}$ & $\begin{array}{l}1998 / \\
99\end{array}$ & $\begin{array}{l}1999 / \\
00\end{array}$ & $\begin{array}{l}1998 / \\
99 \\
\end{array}$ & $\begin{array}{l}1999 / \\
00\end{array}$ & $\begin{array}{l}1998 / \\
99 \\
\end{array}$ & $\begin{array}{l}1999 / \\
00\end{array}$ & $\begin{array}{l}1998 / \\
99 \\
\end{array}$ & $\begin{array}{l}1999 / \\
00\end{array}$ \\
\hline \multirow[t]{4}{*}{ Sweet flag } & 0.0 & $0 \mathrm{e} \dagger$ & $0 \mathrm{~g}$ & Of & Od & $1.3 \mathrm{i}$ & - & - & - & & - & & - \\
\hline & $0.5 \%$ & $8.0 \mathrm{~d}$ & $44 \mathrm{cde}$ & $53.3 b$ & $88 \mathrm{~b}$ & $96.0 \mathrm{ab}$ & - & - & - & - & - & - & - \\
\hline & $1.0 \%$ & $10.7 \mathrm{~d}$ & $68 \mathrm{abc}$ & $96.0 \mathrm{a}$ & $100 \mathrm{a}$ & $100 \mathrm{a}$ & - & - & - & - & - & - & - \\
\hline & $2.0 \%$ & $12.7 \mathrm{~cd}$ & $68 \mathrm{abc}$ & $90.7 \mathrm{a}$ & $100 \mathrm{a}$ & $100 \mathrm{a}$ & - & - & - & - & - & - & - \\
\hline \multirow[t]{4}{*}{ Goat weed } & 0.0 & $0 \mathrm{e}$ & $0 \mathrm{~g}$ & Of & $0 d$ & $1.3 \mathrm{i}$ & $0 \mathrm{e}$ & $5.3 \mathrm{~g}$ & 0 & $9.3 \mathrm{e}$ & 4 & 9.3 & 4 \\
\hline & $0.5 \%$ & $1.3 \mathrm{e}$ & $4 \mathrm{fg}$ & $1.3 b$ & $20 \mathrm{c}$ & 9.3fghi & $32 d$ & $28.0 \mathrm{ef}$ & 44 & $32.0 \mathrm{bcd}$ & 48 & 56.0 & 56 \\
\hline & $1.0 \%$ & $0 \mathrm{e}$ & $12 \mathrm{efg}$ & 9.3def & $32 \mathrm{c}$ & $10.7 \mathrm{efgh}$ & $48 \mathrm{bcd}$ & 20.0efg & 64 & $22.7 \mathrm{~d}$ & 72 & 65.3 & 72 \\
\hline & $2.0 \%$ & $6.7 d$ & $20 \mathrm{def}$ & $5.3 \mathrm{ef}$ & $36 c$ & $6.7 \mathrm{ghi}$ & $56 b c$ & 21.3ef & 68 & 48.0bcd & 80 & 73.3 & 80 \\
\hline \multirow[t]{4}{*}{ Lantana } & 0.0 & $0 \mathrm{e}$ & $0 g$ & Of & Od & $1.3 \mathrm{i}$ & $0 \mathrm{e}$ & $5.3 \mathrm{~g}$ & 0 & $9.3 \mathrm{e}$ & 4 & 9.3 & 4 \\
\hline & $0.5 \%$ & $0 \mathrm{e}$ & $8 \mathrm{fg}$ & $4.0 \mathrm{ef}$ & $20 c$ & $9.3 \mathrm{fgh}$ & $52 \mathrm{bcd}$ & $30.7 \mathrm{ef}$ & 60 & $46.7 \mathrm{bcd}$ & 60 & 77.3 & 64 \\
\hline & $1.0 \%$ & $0 \mathrm{e}$ & 12defg & $5.3 \mathrm{ef}$ & $20 \mathrm{c}$ & $9.3 \mathrm{fgh}$ & $64 b$ & $20.0 \mathrm{ef}$ & 68 & $32.0 \mathrm{bcd}$ & 72 & 52.0 & 76 \\
\hline & $2.0 \%$ & $0 \mathrm{e}$ & $12 \mathrm{fg}$ & $6.7 \mathrm{def}$ & $24 \mathrm{c}$ & 8.0fghi & $68 b$ & 24.0ef & 72 & $48.0 \mathrm{bcd}$ & 76 & 62.7 & 80 \\
\hline Dadelno & 0.0 & $0 \mathrm{e}$ & $0 \mathrm{~g}$ & Of & Od & $1.3 \mathrm{i}$ & $0 \mathrm{e}$ & $5.3 \mathrm{~g}$ & - & $9.3 \mathrm{e}$ & - & 9.3 & - \\
\hline \multirow[t]{3}{*}{ ko Kharani } & $0.5 \%$ & $0 \mathrm{e}$ & $68 \mathrm{bc}$ & $9.3 \mathrm{ef}$ & $100 \mathrm{ab}$ & $22.7 \mathrm{def}$ & $100 \mathrm{a}$ & $44.0 \mathrm{de}$ & - & $57.3 b$ & - & 93.3 & - \\
\hline & $1.0 \%$ & $1.3 \mathrm{e}$ & $80 \mathrm{ab}$ & 16.0de & $100 \mathrm{ab}$ & $28.7 \mathrm{de}$ & $100 \mathrm{a}$ & $61.3 \mathrm{~cd}$ & - & $89.3 a$ & - & 98.7 & - \\
\hline & $2.0 \%$ & $0 \mathrm{e}$ & $88 \mathrm{ab}$ & 18.0de & $100 \mathrm{a}$ & $66.7 \mathrm{c}$ & $100 \mathrm{a}$ & $92.0 \mathrm{ab}$ & - & $100 \mathrm{a}$ & - & 100 & - \\
\hline Indian & 0.0 & $0 \mathrm{e}$ & $0 \mathrm{~g}$ & Of & $0 \mathrm{~d}$ & $1.3 \mathrm{i}$ & $0 \mathrm{e}$ & $5.3 \mathrm{~g}$ & 0 & $9.3 \mathrm{e}$ & 4 & 9.3 & 4 \\
\hline \multirow[t]{3}{*}{ privet } & $0.5 \%$ & $0 \mathrm{e}$ & $8 f g$ & $1.6 \mathrm{f}$ & $32 \mathrm{c}$ & 1.6hi & $44 \mathrm{bcd}$ & 20.0efg & 60 & $37.3 \mathrm{bcd}$ & 64 & 60.0 & 68 \\
\hline & $1.0 \%$ & $0 \mathrm{e}$ & $20 \mathrm{def}$ & $2.7 \mathrm{ef}$ & $36 c$ & 8.0fghi & $52 \mathrm{bcd}$ & $22.7 \mathrm{ef}$ & 68 & $33.3 \mathrm{bcd}$ & 72 & 60.0 & 76 \\
\hline & $2.0 \%$ & $1.3 \mathrm{e}$ & 8defg & $1.3 \mathrm{f}$ & $36 c$ & 14.7defgh & $60 \mathrm{bc}$ & $30.7 \mathrm{ef}$ & 72 & $50.7 \mathrm{bc}$ & 76 & 72.0 & 80 \\
\hline \multirow[t]{4}{*}{ Chinaberry } & 0.0 & $0 \mathrm{e}$ & $0 \mathrm{~g}$ & Of & Od & $1.3 \mathrm{i}$ & $0 \mathrm{e}$ & $5.3 \mathrm{~g}$ & 0 & $9.3 \mathrm{e}$ & 4 & 9.3 & 4 \\
\hline & $0.5 \%$ & $0 \mathrm{e}$ & $4 \mathrm{fg}$ & $5.3 \mathrm{ef}$ & $16 \mathrm{c}$ & 20.0defg & $32 d$ & $24.0 \mathrm{ef}$ & 44 & $33.3 \mathrm{bcd}$ & 52 & 50.7 & 56 \\
\hline & $1.0 \%$ & $0 \mathrm{e}$ & $8 \mathrm{fg}$ & $4.0 \mathrm{ef}$ & $16 \mathrm{c}$ & 8.0fghi & $36 \mathrm{~cd}$ & $10.7 \mathrm{fg}$ & 44 & $24.0 \mathrm{~cd}$ & 60 & 36.0 & 64 \\
\hline & $2.0 \%$ & $0 \mathrm{e}$ & 16defg & $6.7 \mathrm{ef}$ & $32 \mathrm{c}$ & $29.3 d$ & $48 \mathrm{bcd}$ & $36.0 \mathrm{de}$ & 60 & $42.7 \mathrm{bcd}$ & 76 & 56.0 & 76 \\
\hline Mustard & 0.0 & $0 \mathrm{e}$ & $0 \mathrm{~g}$ & Of & $0 \mathrm{~d}$ & $1.3 \mathrm{i}$ & - & $5.3 \mathrm{~g}$ & - & - & - & & - \\
\hline \multirow[t]{3}{*}{ oil } & $0.5 \%$ & $13.3 \mathrm{~d}$ & $48 \mathrm{~cd}$ & $28.0 \mathrm{~cd}$ & $92 b$ & $62.7 \mathrm{c}$ & - & $74.7 \mathrm{bc}$ & - & - & - & - & - \\
\hline & $1.0 \%$ & $21.3 \mathrm{c}$ & $88 \mathrm{ab}$ & $46.7 b c$ & $100 \mathrm{a}$ & $93.3 b$ & - & $100 \mathrm{a}$ & - & - & - & - & - \\
\hline & $2.0 \%$ & $93.3 b$ & $96 a$ & $100 \mathrm{a}$ & $100 \mathrm{a}$ & $100 \mathrm{a}$ & - & $100 \mathrm{a}$ & - & - & - & - & - \\
\hline Neem oil & 0.0 & $0 \mathrm{e}$ & $0 \mathrm{~g}$ & - & $0 \mathrm{~d}$ & - & $0 \mathrm{e}$ & - & 0 & - & 4 & - & 4 \\
\hline$\left(1^{\text {st }}\right.$ Year $)$ & $0.5 \%$ & $100 \mathrm{a}$ & $12 \mathrm{fg}$ & - & $24 \mathrm{c}$ & - & $44 \mathrm{bcd}$ & - & 64 & - & 68 & - & 68 \\
\hline Mug wort & $1.0 \%$ & $100 \mathrm{a}$ & 16defg & - & $32 \mathrm{c}$ & - & $60 \mathrm{bc}$ & - & 68 & - & 68 & - & 72 \\
\hline$\left(2^{\text {nd }}\right.$ Year $)$ & $2.0 \%$ & $100 \mathrm{a}$ & $20 \mathrm{def}$ & - & $36 \mathrm{c}$ & - & $60 \mathrm{bc}$ & - & 76 & - & 80 & - & 84 \\
\hline \multicolumn{14}{|l|}{ F value } \\
\hline Conc. & & $* *$ & $* *$ & $* *$ & $* *$ & $* *$ & $* *$ & $* *$ & $* *$ & $* *$ & $* *$ & $* *$ & $* *$ \\
\hline Treatment & & $* *$ & $* *$ & $* *$ & $* *$ & $* *$ & $* *$ & $* *$ & ns & $* *$ & ns & $* *$ & ns \\
\hline Interaction & & $* *$ & $* *$ & $* *$ & $* *$ & $* *$ & $* *$ & $* *$ & ns & $* *$ & ns & $\mathrm{ns}$ & ns \\
\hline
\end{tabular}

** Significant difference at $\mathrm{P} \leq 0.01$; ns, Non-significant difference. $\dagger$ Means followed by the same letter are not difference at $\overline{5 \%}$.

During the first year, neem oil (@ 0.5\%,1\% and $2 \% \mathrm{v} / \mathrm{w})$ was found superior to other treatment combinations to cause $100 \%$ mortality of the beetles within 2 days. The mustard oil (2\%) caused $>93 \%$ mortality of the beetles within 2 days in the first and second year. On the $4^{\text {th }}$ day, sweet flag rhizome powder (@ 1\% and 2\%) and mustard oil (@2\%) were superior to other treatments to cause high mortality of pulse beetles in the $1^{\text {st }}$ year, while the sweet flag rhizome powder (@1\% and 2\%), mustard oil (@ 1\% and 2\%) and rice husk ash (@ 0.5\%,1\% and $2 \%$ ) were superior in the second year.
On the $6^{\text {th }}$ day, sweet flag powder (@ 1\%,2\%) and mustard oil (2\%) were found superior to cause $100 \%$ mortality of beetles in 1998/99, while $100 \%$ mortality was found within 4 days in $1999 / 00$. On the $8^{\text {th }}$ day, mustard oil ( $1 \%$ and $2 \%$ ) caused $100 \%$ mortality of beetles in the $1^{\text {st }}$ year, while $100 \%$ mortality was recorded at same concentrations within 4 days. On $10^{\text {th }}$ and $12^{\text {th }}$ day, rice husk ash (@1\% and 2\%) caused > 89\% mortality of beetles in the first year, while $100 \%$ mortality was observed even at $0.5 \%$ concentration within 6 days in the second year. 
The treatments, which caused $100 \%$ mortality of the beetles at all concentrations except in respective control were excluded for further analysis. The mortality caused by remaining treatments on later dates was found no-significant different at $\mathrm{P} \leq 0.05$ indicating the similar response in killing the beetles.

Based on two years results, the sweet flag rhizome powder, rice husk ash and mustard oil have shown high bruchid killing properties at 0.5 , 1 and $2 \%$ concentrations. The neem oil was also observed very effective to kill the insect within 2 days. Other tested materials were found to have some effects in killing the pulse beetle but the rate of killing in the given time was comparatively lower than those of neem oil, mustard oil and sweet flag rhizome powder. The other evidences indicated similar effects of botanicals to stored grain beetle as well. Sweet flag rhizome powder mixed with lentil may not have any side effect on seed germination as in the case of powder mixed with wheat grains did not have any side effects on germination (Paneru et al., 1997). However, the effects of mustard oil and rice husk ash on germination of treated seeds is yet to be known. Farmers are very familiar to sweet flag rhizome powder and rice husk ash. These materials are easier to prepare and apply than other products. Thus, rice husk ash and sweet flag rhizome powder at $0.5 \%$ concentration would be the best choice among the botanicals for management of pulse beetle.

\section{Acknowledgements}

The authors are thankful to Mr DN Manandhar, the Chief of Entomology Division, Khumaltar for providing facilities to conduct the experiment. The authors also acknowledge Mr YP Giri, Senior Scientist, Entomology Division for his guidance during data analysis. The technical help of Messrs A Mandal and RK Shrestha, Entomology Division, Khumaltar, during data recording and conducting the experiment are duly acknowledged.

\section{References}

Abott, WS. 1925. A method of computing the effectiveness of insecticides. J. Econ. Ento. 18:265-267.

Bayeh, M and G Tadese. 1996. Suppressing effect of different botanicals on the adzuki bean beetle. In: Proceedings of the $3^{\text {rd }}$ Annual Conference of the Crop Protection Society of Ethiopia (CPSE) (EB Yemana, ed.). Addisabeba, Ethiopia.

Chinwada, PC and DP Giga. 1993. Vegetables and neem oils as protectants of stored grains against bruchid. Meeting of the Pan -Africa working group on bean entomology, Harare, Zimbawe, 19 - 22, Sept 1993. CIAT Workshops Series No. 25.

Garcia, JRJ. 1990. Bioassay of five botanical materials against the bean weevil (Challosobruchus chinensis L.) on mung bean. College Laguna (Philippines), University of Phillippines, Laguna, Los Banos, the Philippines.

Negasi, F and T Abage. 1992. Progress in bean bruchid management. In: Proceedings of the Third Workshop on Bean Research. SADC/CIAJ, Mbabane, Swaziland, 5-7 Oct 1992.

Pandey, RP. 1994. Masuro Ma Lagne Pramukh Kiraharu Ra Tinko Bebasthapan Ka Tarikaharu. Legume Research Program, Nepal Agricultural Research Council, Rampur, Nepal (in Nepali).

Paneru, RB, VR Duwadi and R Khanal. 1997. Study on the effect of different doses of Bojo rhizome dust (Acorus calamus L.) against weevil on stored wheat grains. In: PAC Technical Paper No 173. Pakhribas Agriculture Centre, Dhankuta, Nepal.

Rojesus, BM, HA Maini, K Ohsawa and L Yamamoto. 1989. Insecticidal actions of several plants to Callosobruchus chinensis L. International symposium on bruchids and legumes. Okayama, Japan, 6-9 Sept 1989. 